\title{
Jak gender studies wpływa na przyszłość bibliotek akademickich? Wizja biblioteki uniwersyteckiej według Roberta Darntona
}

STRESZCZENIE: Artykuł jest próbą rekonstrukcji poglądów Roberta Darntona (profesora, dyrektora Biblioteki Uniwersytetu Harvarda) dotyczących książki, biblioteki, publikacji naukowych oraz ich niedalekiej przyszłości. Darnton odszyfrowuje błędne koło, w jakim znaleźli się ludzie nauki - bibliotekarze, naukowcy, wydawcy monografii. Swoista matnia zaczyna się od wysokich cen czasopism. Biblioteki, płacąc za dostarczanie publikacji ciągłych, nie mają już pieniędzy na zakup monografii. A skoro nikt - nawet książnice - nie kupują prac naukowych, to wydawcy nie chcą ich wydawać, bo to nie przynosi im zysku. Swoisty chocholi taniec może przerwać tylko zmiana światopoglądowa, tj. przejście naukowców na publikowanie w otwartych źródłach.

Publikacje naukowe, wydawane przez konsorcja wydawnicze, powstają dzięki państwowym grantom, z pieniędzy publicznych, a dla podatników są niedostępne. Biblioteki muszą same opłacać dostęp do prac swoich czytelnikówprofesorów. Taki stan rzeczy budzi sprzeciw intelektualistów, którzy postanowili udostępniać swoje artykuły na otwartych licencjach. Gdyby w ślad za nimi poszły także uczelnie oraz instytucje naukowe, które usankcjonowałyby taki proces, zwyczaj pod kątem prawnym, możliwy byłby rozwój badań niezależnych, niepozostających w zasięgu finansowania sektora przemysłowego czy gospodarczego, badań humanistycznych, które byłyby kwintesencją nauki.

* Uczestniczka studiów doktoranckich z zakresu bibliologii, prowadzonych na Wydziale Nauk Historycznych Uniwersytetu Mikołaja Kopernika w Toruniu. 
SŁoWA KLuCzowE: biblioteki akademickie, Darnton Robert (1939-), gender studies, Open Access

\section{Wprowadzenie}

Dozornie nieoddziałujące na siebie dwa elementy kultury: biblioteki akademickie oraz gender studies - nauka, która w swoim obszarze badawczym skupia się na analizie tekstów kultury pod kątem tożsamości płciowej, zostają powiązane przez Roberta Darntona w jedno ogniwo, wpływające na przyszłość i funkcjonowanie obecnych bibliotek naukowych, wydawnictw uniwersyteckich oraz dysertacji. Te trzy elementy systemu naukowego, jaki działa na każdym uniwersytecie, Darnton sprowadza do wspólnego mianownika, ukazując wzajemność ich relacji i zależność względem siebie. Udowadnia tym samym, że tworzą one nierozerwalną całość, wpływając na funkcjonowanie uczelni i nauki w społeczeństwie oraz zmieniając dotychczasowy system szkolnictwa wyższego. Gender studies są tu symbolem wszystkich nauk modnych, cieszących się popularnością wśród naukowców oraz wśród czytelników. Nauki te stoją w opozycji do dziedzin mniej popularnych, niszowych, które przez swoją unikatowość nie znajdują wydawcy, a tym samym odbiorcy.

Poglądy Darntona na funkcjonowanie bibliotek naukowych, e-publikacji, tradycyjnych czy papierowych dysertacji, humanistyki, a także działalności wydawnictw naukowych zostały ukształtowane przez jego wieloletnie studia, dotyczące m.in. oświeceniowego rynku książki we Francji, oraz wszechstronne doświadczenie w prowadzeniu, nadzorowaniu, a także doradzaniu różnym instytucjom naukowym i kulturalnym, działającym na całym świecie. Dodatkowo jego wizja została poparta praktyką w zarządzaniu harwardzką biblioteką uniwersytecką. Taka działalność dała Darntonowi możliwość obserwacji zmian, jakie zachodziły w procesach bibliotecznych i naukowych. Dzięki temu może on w swoich artykułach wyjaśniać, opisywać i zwracać uwagę na konkretne rozwiązania i problemy, jakie towarzyszą ludziom książki na każdym etapie jej tworzenia i udostępniania, a nawet czytania. Jako dyrektor jednej z największych bibliotek naukowych na świecie jest także ambasadorem Open Access. Kieruje się oświeceniową zasadą - wszyst- 
ko dla wszystkich za darmo, gdyż dobro publiczne jest dobrem najwyższym, a biblioteki są instytucjami, które mają tę ideę realizować1.

Darnton jest jednym ze współczesnych wizjonerów przyszłości bibliotek. Jego wizja stoi jednak w opozycji do profetycznych głosów o śmierci książki i biblioteki. On patrzy na tę kwestię realistycznym okiem - książka nie umrze, jest na to za wcześnie, ale humanistyka będzie rozwijała się tylko dzięki książkom elektronicznym.

\section{Robert Darnton}

Robert Darnton urodził się 10 maja 1939 r. w Nowym Jorku. Wykształcenie wyższe zdobył na Uniwersytecie Harvarda oraz w Oxfordzie, gdzie przebywał na stypendium Rhodesa. W 1964 r. obronił pracę doktorską z historii. Pracował jako reporter w „New York Times”. Z pracy tej zrezygnował, gdy został wybrany do Harvard Society of Fellows. Od 1968 r. pracował na stanowisku adiunkta w Princeton, gdzie w latach 1987-1995 był dyrektorem Program in European Cultural Studies oraz Center for the Study of Books and Media (2002-2007). Od 2007 r. jest profesorem Harvard University i dyrektorem biblioteki uniwersyteckiej. Był członkiem wielu towarzystw, stowarzyszeń i ciał doradczych². Współpracował z Collège de France oraz z wydawnictwem uniwersytetu w Oxfordzie. Został wyróżniony wieloma nagrodami na całym świecie, np. w 2004 r. Gutenberg Prize of the International Gutenberg Society and the City of Mainz, a w 2005 r. Lifetime Achievement Award of the American Printing History Association. Od wielu uczelni otrzymał honorowy doktorat ${ }^{3}$.

${ }^{1}$ R. Darnton, Google \& the Future of Books. The New York Review of Books [online] 2009, no. 2, vol. 56 [dostęp 30 listopada 2012]. Dostępny w World Wide Web: http://www.nybooks.com/articles/archives/2009/feb/12/google-the-future-ofbooks/?pagination=false.

${ }_{2}^{2}$ M.in. American Academy of Arts and Sciences, American Philosophical Society, American Antiquarian Society, Massachusetts Historical Society, Academia Europaea, Académie Royale de Langue et de Littérature Françaises (Belgium), British Academy, American Society for Eighteenth-Century Studies, Program in the History of the Book in American Culture, American Antiquarian Society 1985-2000. Zasiadał w radach redakcyjnych: „Revue de synthèse”, „History of the Human Sciences”, „Wilson Quarterly”, „Communication”, „Intellectual History Newsletter”. Za: R. Darnton, Curriculum vitae [on-line]. Harvard University. History Department [dostęp 30 listopada 2012]. Dostępny w World Wide Web: http://history.fas.harvard.edu/people/faculty/documents/darnton-cv.pdf.

3 Tamże. 
Darnton jest autorem ponad 24 książek dotyczących oświecenia oraz historii Wielkiej encyklopedii francuskiej. Najpopularniejsza praca Darntona to The Great Cat Massacre and Other Episodes in French Cultural History, przetłumaczona na 16 języków ${ }^{4}$. Na łamach „The New York Review of Books" prowadzi kampanię promującą Open Access. W swoich eseistycznych publikacjach Darnton zwraca uwagę naukowców na potrzebę rozwijania otwartej nauki, digitalizacji dzieł literackich oraz inwestowania w biblioteki. Promując ideę otwartej edukacji i nauki wśród kadry akademickiej, używa wielu argumentów, które są znane także na gruncie polskim.

\section{„Publikuj albo giń"}

Podstawą funkcjonowania w świecie naukowym jest publikowanie. Obecny system oceny dorobku naukowego w Stanach Zjednoczonych sprawia, że młodzi naukowcy, doktoranci muszą legitymować się określoną liczbą publikacji. Bibliometria i wewnątrzuczelniane procedury oceny pracowników są bezlitosne dla osób, które mają zbyt małą liczbę wydanych artykułów lub monografii. Sam system takiej oceny pozostawia wiele do życzenia, jednak nie to stanowi clou sprawy.

Aby wprowadzić pewne nowe elementy do nauki, młodzi naukowcy szukają wąskich pól badawczych i zakresów tematycznych. Specjalizują się w coraz bardziej szczegółowych dziedzinach wiedzy, przygotowują coraz bardziej niszowe dysertacje. Wydawnictwa naukowe, które publikują te prace, skazują się na powolne bankructwo, gdyż nabywców specjalistycznych monografii czy syntez naukowych jest na rynku książki niewielu. Jedynymi pewnymi odbiorcami są biblioteki naukowe, do tej pory wykupujące prawie całe nakłady tych dysertacji. Gdy wydawnictwa wiedzą, że książka z jakiejś dziedziny się nie sprzeda, nie chcą jej wydać. Biblioteki naukowe w USA przestały kupować książki, gdyż muszą kontynuować zakup czasopism, które z roku na rok są coraz droższe i rujnują ich budżety. Młody naukowiec znajduje się w bardzo trudnej sytuacji - zajmując się badaniami z niepopularnej dziedziny wiedzy, których wyników nie będzie mógł opublikować, blokuje sobie możliwość wspinania

${ }^{4}$ Faculty: Robert Darnton [on-line]. Harvard University. History Department [dostęp 30 listopada 2012]. Dostępny w World Wide Web: http://history.fas.harvard.edu/people/ faculty/darnton.php. 
się po szczeblach kariery naukowej. Jego przyszłość staje zatem pod znakiem zapytania. 0 trudnej sytuacji naukowca Darnton pisze tak: „Niektórzy niezależni badacze cieszą się swoją niezależnością [...]. Ale nawet najbardziej niezależni uczeni muszą w trudzie zarabiać na życie, wykonując prace dorywcze, gdziekolwiek mogą je znaleźć, zazwyczaj słabo płatne, bez świadczeń i prestiżu”.

Dodatkowo taka działalność wydawnictw naukowych sprawia, że w procesie rozwoju nauki powstają duże ubytki. Folklorystyka, publikacje lokalne czy gender studies są intensywnie reprezentowane na rynku wydawniczym (bo się sprzedają), a tym samym w dorobku naukowym z tej problematyki: „Wielu wydawców próbowało znaleźć wyjście z impasu, koncentrując się na tematach aktualnych, będących w modzie, takich jak: książki o tematyce gender, feminizmie, homoseksualizmie, afroamerykanizmie, postkolonializmie i postmodernizmie wszystkich odmian"6. Na horyzoncie humanistyki pozostają jednak czarne plamy, które prawdopodobnie nie będą już możliwe do rozjaśnienia, m.in. na polu dotyczącym badań historycznych.

Skupianie się wyłącznie ma modnych tematach z zakresu humanistyki zaburza swoisty ekosystem naukowy. Przyrost wziętych tematycznie publikacji sprawia, że są one intensywnie reprezentowane w bibliotekach naukowych, natomiast niektóre dziedziny wiedzy, mniej popularne, są zaniedbane. Wydawcy wycofują i blokują rozwój całych obszarów nauki W takiej sytuacji nie można powiedzieć, że biblioteka gromadzi przekrój piśmiennictwa naukowego.

Problem z kompletowaniem kolekcji w bibliotece to jedynie skutek zaburzenia systemu, zniekształcającego także rozwój instytucji na-

${ }^{5}$ R. Darnton, The New Age of the Book. The New York Reviev of Books [online] 1999, no. 5, vol. 46 [dostęp 30 listopada 2012]. Dostępny w World Wide Web: http://www.nybooks.com/articles/archives/1999/mar/18/the-new-age-of-thebook/?pagination=false: „Some independent scholars rejoice in their independence. [...] But most independent or adjunct scholars have to scramble for a living, picking up odd jobs wherever they can find them, usually for inadequate pay, insufficient benefits, and no recognition".

6 Tamże: „Many presses tried to find a way out of the impasse by concentrating on subjects currently in vogue: books about gender, sex, feminism, homosexuality, lesbianism, women's studies, African-American studies, postcolonialism, and postmodernism of all varieties".

7 R. Darnton, Old books and e-books. European Review [on-line] 2007, no. 2, vol. 15 [dostęp 30 listopada 2012]. Dostępny w World Wide Web: http://dash.harvard.edu/bitstream/handle/1/3403051/darnton_ebooks.pdf?sequence=2. 
ukowych oraz dekompletującego kształcenie, gdyż studenci nie mają potrzebnych im, mało popularnych, opracowań tematycznych. Sytuacja ta jest bardzo złożona, a jej konsekwencje staną się odczuwalne dopiero za jakiś czas. Powszechny marazm może być przerwany tylko przez jedno zjawisko - Open Access (dalej: OA), które umożliwi młodym pracownikom naukowym publikowanie swoich prac, nawet tych najbardziej niszowych, i zdobywanie punktów niezbędnych do awansu oraz rozwoju naukowego. Wydawanie odpowiednio przygotowanych dysertacji naukowych jako e-booków daje ogromne możliwości typograficzne, marketingowe i naukowe. Naukowa książka interaktywna nie ogranicza pomysłowości autora, który nie musi przejmować się jej strukturą i formą. Ten nowy model publikowania syntez czy monografii naukowych wprowadził naukowców w inną rzeczywistość, w której mogą używać prekursorskich technik, dających nieograniczone możliwości.

\section{Śmierci książi nie będzie}

E-publikowanie otwiera nowe możliwości przed autorami dysertacji naukowych. Okazuje się, że książka nie musi mieć sztywnej i schematycznej formy, ale może zawierać w swojej strukturze filmy, muzykę, obrazy, zdjęcia itp. Tradycyjne publikacje nie mogą być wzbogacone przez redaktorów o "rękopisy, obrazy, nagrania, filmy i hiperłącza do innych prac”, na co pozwala właśnie e-monografia. Hipertekst, stanowiący nieodłączny element elektronicznych publikacji, stwarza nowe możliwości, które w książce tradycyjnej nigdy by się nie pojawiły. Darnton nie mówi jednak o e-booku jako o panaceum na niestabilną sytuację na rynku książki naukowej. Tego rodzaju książki wymagają nowego sposobu czytania - na płaszczyźnie horyzontalnej, wertykalnej lub zygzakiem (ang. diagonal zigzagging, tj. czytanie książki polegające na kreśleniu na niej wskaźnikiem odwróconej litery S na każdej stronie z tekstem): „Tego rodzaju książki wymagają nowego sposobu czytania, wertykalnego, jak i horyzontalnego. Może to również obejmować diagonalne zygzaki, bo mam zamiar przeplatać każdy sektor mapami, współczesnymi grafikami górskimi, scenami z miejskich ulic, a także hiperłączami do powiązanych tematów"9.

8 Tamże.

9 Tamże: „This kind of book will require a new kind of reading, one that proceeds vertically as well as horizontally. It could also involve diagonal zigzagging, because I plan 
Każdy czytelnik będzie musiał znaleźć swój własny sposób na czytanie takiej książki, a program umożliwi mu drukowanie interesujących go fragmentów. „Książki nowego rodzaju wymuszą nowy sposób czytania. Niektórzy czytelnicy mogą być zadowoleni ze studiowania lepszej narracji. Inni może również chcą czytać wertykalnie, realizując pewne tematy coraz głębiej"10.

Mimo niewątpliwych zalet e-booków, Darnton widzi także ich minusy, np. zmiany w sposobie czytania. Szeroka i łatwa dostępność elektronicznych publikacji kończy jednak dyskusję o tym, czy są one przydatne. Odpowiedź jest pozytywna. Podobnie jest z czasopismami, do których „otwierania” zachęca Darnton.

Sytuacja na rynku czasopism naukowych to jedna z przyczyn kryzysu w bibliotekach, którym potrzebne są głębokie zmiany systemowe. Do tej pory biblioteki dzieliły swój budżet na pół: między zakup czasopism i zakup monografii. Obecnie, kiedy konsorcja, które dostarczają czasopisma do bibliotek, stale podnoszą ceny, ta równowaga finansowa została zachwiana, a niektóre biblioteki w ogóle przestały kupować tradycyjne książki. To z kolei wpływa na trudną sytuację wydawnictw i preferowanie publikowania wyłącznie modnych tematów.

Profesura i młodsi naukowcy oczekują stałego i ciągłego dostępu do najnowszych publikacji, ukazujących się w czasopismach. Biblioteki, aby sprostać tym oczekiwaniom, subskrybują i prenumerują więc niezbędne materiały, co wpływa na wzbogacenie się prywatnych konsorcjów. Wydawcy czasopism zarabiają ogromne pieniądze na nie swoich osiągnięciach: nie płacą honorariów autorom tekstów, a profesura zasiada w radach, kolokwiach, gremiach redakcyjnych, recenzuje artykuły i nie pobiera za to pieniędzy. Argumentem natomiast, który przesądza o tym, że wydawcy zarabiają, nie inwestując $w$ to ani grosza, jest fakt, że to nie oni finansują badania, których wyniki publikują, a wręcz przeciwnie: „skutki tąpnięcia zniszczyły życie intelektualne w całym świecie nauki"11.

to intersperse each sector with maps, contemporary engravings of mountain passes, scenes of city streets, accounts of life in country inns, and hyperlinks to related themes in other dossiers".

${ }^{10}$ R. Darnton, The New Age of the Book...: „A new book of this kind would elicit a new kind of reading. Some readers might be satisfied with a study of the upper narrative. Others might also want to read vertically, pursuing certain themes deeper and deeper into the supporting essays and documentation".

11 Tamże: „the ripple effects have demaged intellectual life throughout the Word of learning". 
Ten powód powinien przemówić do wyobraźni naukowców i zachęcić ich do tego, żeby swoje badania publikowali w sieci za darmo.

Badania są najczęściej finansowane przez instytucje naukowe albo fundacje w systemie grantowym - z pieniędzy publicznych. Coś, co finansuje ogół społeczeństwa, podatnicy, jest udostępniane tylko nielicznym, i to za opłatą, która przekracza wszelkie granice przyzwoitości ${ }^{12}$. Wydawcy natomiast sprzedają bibliotekom dostęp do czasopism za sumy rujnujące ich budżety i hamujące rozwój młodych naukowców. Ci nie mogą bowiem wydać swoich pierwszych dysertacji, ponieważ dla wydawnictw, których głównym odbiorcą były do tej pory biblioteki (dopóki miały pieniądze, kupowały publikacje bez względu na ich modową atrakcyjność), nie są to książki przynoszące zysk. Niektóre środowiska naukowe zdecydowały się na eksperymentalne udostępnianie swoich artykułów i najnowszych wyników badań w ramach Open Access. Skoro badania, pensje i granty są przyznawane ze środków publicznych, państwowych, nie ma sensu odcinać od nich społeczeństwa, a dodatkowo działać na szkodę własnej uczelni. Okazuje się, że eksperyment się udał: „Na Harvardzie stworzyliśmy nowy model. W drodze jednomyślnego głosowania dnia 12 lutego 2008 r. profesorowie Wydziału Sztuk i Nauk zobowiązali się do złożenia wszystkich swoich przyszłych artykułów naukowych w repozytorium w formie Open Access, w miejscu ustalonym przez bibliotekę, przekazując także prawa do dystrybucji na ręce uczelni” ${ }^{13}$.

Czasopisma wydawane $\mathrm{w}$ ramach OA mają większą liczbę cytowań niż publikacje komercyjne ${ }^{14}$, co oznacza, że docierają do szerszej liczby odbiorców niż tradycyjne czasopisma, nawet te wydawane on-line, ale za dostęp do nich trzeba zapłacić. Jednak taki stan rzeczy będzie możliwy wyłącznie wtedy, gdy profesura i młodzi adepci nauki zmienią sposób myślenia oraz postrzegania czasopism OA. Kiedy już świat naukowy zmobilizuje się do pewnej walki o dobro uczelni, swoje i studentów, konsorcja dostarczające czasopisma do instytucji naukowych będą musiały zracjo-

12 Tamże.

13 R. Darnton, The Library: Three Jeremiads. The New York Review of Books [online] 2010, no. 20, vol. 57 [dostęp 30 listopada 2012]. Dostępny w World Wide Web: http://www.nybooks.com/articles/archives/2010/dec/23/library-three-jeremiads /?pagination=false: „At Harvard we developed a new model. By a unanimous vote on February 12, 2008, professors in the Faculty of Arts and Sciences bound themselves to deposit all of their future scholarly articles in an open-access repository to be established by the library and also granted the university permission to distribute them".

14 Tamże. 
nalizować ceny, jakich oczekują za dostęp do swoich produktów. Biblioteki będą wtedy miały więcej funduszy na inne działania lub zakupy, które uzupełnią ich kolekcje. Obecności e-zasobów nie uda się już jednak uniknąć ani w bibliotece, ani w wydawnictwie naukowym. Może okazać się, że nowa technologia druku na żądanie (ang. print-on-demand) pobudzi rynek książki. Osoby zainteresowane określoną publikacją będą mogły albo same, albo z pomocą wydawnictwa wydrukować sobie dowolny fragment książki, połączyć go z innym i mieć spersonalizowaną publikację, dostosowaną do swoich indywidualnych potrzeb.

\section{E-booki w bibliotecznym świecie}

Przyszłością bibliotek naukowych jest udostępnianie zbiorów on-line, pomoc czytelnikowi w odnalezieniu się w szumie informacyjnym oraz nauczenie go, że informacje znalezione w sieci trzeba weryfikować, gdyż bardzo łatwo można dać się oszukać ${ }^{15}$. Sytuacja społeczna bibliotek naukowych zmienia się:

Dla studentów w latach 50. XX wieku biblioteki były twierdzami nauki. Wiedza leżała między twardymi okładkami, a wielka biblioteka wydawała się zawierać to wszystko. [...] Studenci nadal cenią biblioteki, mimo że część czytelni świeci obecnie pustkami. Aby zachęcić czytelników do powrotu, niektórzy bibliotekarze zaczęli oferować wygodne fotele, możliwość relaksu, a nawet napoje i przekąski. Jednakże współcześni studenci większość swoich badań wykonują, używając laptopa. Dla nich wiedza pochodzi z Internetu, nie z bibliotek. Ich zdaniem biblioteka nie jest w stanie zaspokoić głodu informacji, ze względu na swoje ograniczenia, a przecież informacja jest nieskończona. Wiedzą, że biblioteki nie mogą zawierać tego, co można znaleźć w Internecie. Uważają, że aby dotrzeć do informacji, należy użyć wyszukiwarki internetowej, a nie katalogu kartkowego ${ }^{16}$.

15 Tamże.

${ }^{16}$ R. Darnton, The Library in the New Age. The New York Review of Books [online] 2008, no. 10, vol. 55 [dostęp 30 listopada 2012]. Dostępny w World Wide Web: http://www.nybooks.com/articles/archives/2008/jun/12/the-library-in-the-newage/?pagination=false: „To students in the $1950 \mathrm{~s}$, libraries, libraries looked like citadels of learning. Knowledge came packaged between hard covers, and a great library seemed to contain all of it. [...] Students today still respect their libraries, but reading rooms are nearly empty on some campuses. In order to entice the students back, some librarians of- 
Stworzenie biblioteki bez ścian okazało się możliwe szybciej, niż się komukolwiek mogło zdawać ${ }^{17}$. Czy teraz możliwa jest biblioteka bez kodeksów, zawierająca wyłącznie e-booki? Darnton podkreśla, że biblioteki powinny rozwijać się dwutorowo ${ }^{18}$ : udostępniać kolekcje cyfrowe oraz gromadzić tradycyjny księgozbiór. Można się zastanawiać, dlaczego kontynuowanie gromadzenia tradycyjnych publikacji ma sens. Darnton odpowiada bardzo prosto: bo musimy mieć podstawę, fundament, do którego będziemy mogli zawsze się odnieść. Na przestrzeni historii piśmiennictwa to właśnie papier okazał się medium najbardziej trwałym ${ }^{19}$. Demokratyzacja nauki, prowadzenie jej w zespołach, które mogą wszystko zmieniać i udoskonalać, sprawia, że musimy mieć bazę, do której będzie można się odwołać w razie jakichkolwiek wątpliwości. Bardzo znamienny jest przykład Szekspira. Gdyby nie to, że Henry Clay Folger ${ }^{20} \mathrm{z}$ uporem maniaka gromadził dzieła dramaturga, to prawdopodobnie nigdy nie dotarlibyśmy do pierwotnych wersji jego tragedii, gdyż nie zachowały się żadne inne autografy, a istniejące wydania były niepełne i niedokładne. Nie można by więc odtworzyć tekstu pierwotnego. Zgromadzone przez Folgera egzemplarze pierwszej edycji pozwoliły na wysnucie hipotez dotyczących oryginalnego brzmienia tekstów, tj. takiego, jakiego życzyłby sobie autor.

Dodatkowym elementem, który utwierdza Darntona w przekonaniu o potrzebie gromadzenia kodeksów, jest fakt, że produkcja książek wciąż rośnie. Nakład określonych tytułów spada ${ }^{21}$, wzrasta jednak ogólna liczba publikacji. Biblioteki nie mogą ignorować tego przyrostu tylko dlatego, że ich czytelnicy są teraz digital natives ${ }^{22}$. Liczba tytułów wydawanych na całym świecie jest większa niż kiedykolwiek w przeszłości. Natomiast rozwój zasobów cyfrowych jest nieunikniony, gdyż nieuniknione jest przeniesienie wydawania publikacji naukowych do środowiska elek-

fer them armchairs for lounging and chatting, even drinks and snacks, never mind about the crumbs. Modern or postmodern students do most of their research at computers in their rooms. To them, knowledge comes online, not in libraries. They know that libraries could never contain it all within their walls, because information is endless, extending everywhere on the Internet, and to find it one needs a search engine, not a card catalog".

17 Tenże, The New Age of the Book...

18 Tenże, The Library: Three Jeremiads...

19 Tenże, The New Age of the Book...

20 Tenże, The library in the New Age...

${ }^{21} \mathrm{~W}$ rozmowie z redaktorem jednego $\mathrm{z}$ wydawnictw uniwersyteckich autorka niniejszego artykułu uzyskała informację, że w Polsce drukuje się ok. 100-150 egz. danej monografii, a resztę dodrukowuje się w miarę zapotrzebowania.

${ }^{22}$ R. Darnton, The Library: Three Jeremiads... 
tronicznego, w formach e-booków czy też repozytoriów OA. Wszystkie te działania będą wymuszone przez ekonomię - tę, o której mówimy przy kosztach publikacji, i tę, o której można mówić przy udostępnianiu. Uzupełnianie kolekcji tradycyjnej e-publikacjami sprawi też, że w bibliotece znikną białe plamy - luki w księgozbiorach dziedzin, w których wydawanie kodeksu jest nieopłacalne.

Tworząc kolekcje cyfrowe, biblioteki budują jedną globalną bibliotekę cyfrową. W Bibliotece Uniwersytetu Harvarda w tym celu jest prowadzony Open Collection Program, który pozwala na dzielenie się publikacjami z całym cyfrowym światem. Mimo starań instytucji naukowych, rządów i bibliotek monopolistą w zakresie digitalizacji dokumentów jest Google, który skanuje i udostępnia książki w sieci. Darnton przestrzega, że Google jest firmą, która zarabia na udostępnianiu publikacji on-line, wykorzystując biblioteki jako dostarczycieli książek. Google stał się największą na świecie biblioteką i biznesem książkowym ${ }^{23}$, natomiast biblioteki nic nie zarabiają na swojej działalności. Rozsądnym rozwiązaniem byłoby, gdyby Google udostępnił swoje bazy na dogodnych warunkach, obecnie każe bowiem płacić sobie za dostarczanie subskrypcji dla bibliotek, $63 \%$ swoich zysków oddając autorom i wydawcom. Jest to zatem przedsiębiorstwo, tylko wyglądające jak biblioteka, w rzeczywistości najważniejsze są dla niego profity. Dla książnic natomiast najważniejsze jest dobro publiczne ${ }^{24}$. Dodatkowo Google stosuje strategię „syndromu ceny za kokainę”: „strategia pozostawania cen na niskim poziomie w początkowym okresie, a następnie, po zdobyciu klientów, wywindowania ich jak najwyżej to możliwe"25.

Praca, jaką wykonuje Google, jest potrzebna i użyteczna oraz ze wszech miar słuszna. Szczególnie z punktu widzenia małych miast, które dzięki usłudze Google Books mają swobodny dostęp do szerokiego źródła wiedzy. Jednak musimy pamiętać, że Google, tworząc bibliotekę bez ścian, naruszył wiele przepisów i stał się monopolistą na rynku. Wielu autorów i wydawców wytoczyło mu zbiorowy proces. Sąd Rejonowy dla Południowego Okręgu Nowego Jorku (US District Cort for the Souther District of New York), aby zapobiec monopolistycznemu zarządzaniu informacją przez Google, wymusił na nim zagwarantowanie dostępu do swojej

\footnotetext{
23 Tamże.

24 R. Darnton, Google \& the Future of Books...

25 Tenże, The Library: Three Jeremiads...: „a strategy of beginning at a low rate and then, when customers are hooked, ratcheting up the price as high as it will go".
} 
bazy w każdej bibliotece publicznej w Stanach Zjednoczonych ${ }^{26}$. Dodatkowo przy każdej książce musi pojawić się odnośnik „Znajdź w bibliotece”, informujący użytkownika, w której najbliższej jego lokalizacji bibliotece znajduje się interesująca książka ${ }^{27}$.

Google skazał biblioteki na komercjalizację, nie mając równych sobie konkurentów. Biblioteki, które zawarły porozumienie z Google, nie mogą bowiem tworzyć swoich kolekcji cyfrowych. Dostają, co prawda, darmowy egzemplarz zdigitalizowanej książki do swojej kolekcji, jednak nie mogą stworzyć własnego dostępu do odczytania ich oraz łączyć tych kopii z kopiami innych bibliotek, które otrzymały od Google swoje wersje. Ponadto, zgodnie z postanowieniem sądu, Google w swojej usłudze Book Search ma udostępniać $20 \%$ książki w sieci za darmo. Praktyka jest jednak taka, że w przypadku książek wyszukanych za pomocą hasła przedmiotowego można przeczytać on-line tylko tę stronę, którą wyświetliła wyszukiwarka, oraz dwie, które ją poprzedzają i następują po niej. Przesuwając suwak przeglądarki, użytkownicy będą mogli przejść do bardziej oddalonych fragmentów, ale tylko do jednej piątej tekstu i do żadnego fragmentu w ciągu piętnastu stron ${ }^{28}$.

Dodatkowym argumentem przytaczanym przez Darntona jest fakt, że Google nie digitalizuje najlepszych i najrzadszych wydań, a skupia się głównie na tych najłatwiej dostępnych. Ponadto nie zatrudnia w swoim projekcie bibliografów, którzy w najbardziej fachowy sposób dokonaliby przeglądu piśmiennictwa przeznaczonego do cyfryzacji oraz profesjonalnie przygotowaliby te edycje do skanowania. Inżynierowie pracujący nad tym w Google nie są specjalistami z zakresu nauk bibliologicznych, a co za tym idzie, książka nie jest dla nich obiektem badań. Stanowi jedynie materiał, który trzeba powielić. Takie uchybienia, jak braki stron, nieczytelne strony, odciski palców, można poprawić, ale skanowania i upowszechniania niepoprawnych, złych, szkolnych edycji nie da się tak łatwo cofnąć ${ }^{29}$.

${ }^{26}$ Tenże, Old books and e-books...

27 Tenże, Google's Loss: The Public's Gain. The New York Reviev of Books [on-line] 2011, no. 7, vol. 58 [dostęp 30 listopada 2012]. Dostępny w World Wide Web: http://www.nybooks.com/articles/archives/2011/apr/28/googles-loss-publics-gain/?pagination=false.

${ }^{28}$ A. Lewis, P. N. Courant, L. Farley i in., Google \& the Future of Books: An Exchange. The New York Review of Books [on-line] 2010, no. 1, vol. 57 [dostęp 30 listopada 2012]. Dostępny w World Wide Web: http://www.nybooks.com/articles/archives/2010/jan/14/google-the-future-of-books-an-exchange/?pagination=false.

${ }_{29}$ R. Darnton, The New Age of the Book... 
Kolejny problem to nieumiejętność przewidywania, jakie publikacje będą potrzebne do pracy naukowej i specjalistycznej przyszłym pokoleniom. Inną sprawą jest to, czy przyszłe pokolenia będą miały na czym odczytać skany przygotowane przez Google. Czytniki i inne urządzenia do przetwarzania oraz udostępniania zmieniają się dynamicznie. Zagwarantowanie, że znajdziemy za kilka lat urządzenia do odtworzenia skanów wykonanych w obecnych technologiach, jest bardzo nieodpowiedzialne: „Elektroniczne przedsiębiorstwa pojawiają się i znikają. Biblioteki naukowe istnieją na przestrzeni wieków ${ }^{30 "}$.

Papier okazuje się najtrwalszym i uniwersalnym nośnikiem, gdyż do jego odczytu wystarcza jedynie znajomość kodu, „technologię” czytania wypracowywano przez wieki.

Rozwiązaniem tych wszystkich problemów byłoby stworzenie amerykańskiej biblioteki cyfrowej, w której biblioteki digitalizowałyby swoje zasoby, udostępniane następnie w centrum narodowym, w jednej sieci, w jednej bazie. Kongres musiałby odpowiednio znowelizować prawo, aby ta biblioteka nie napotykała problemów prawnych z książkami wydanymi na terenie USA, które są obłożone prawem autorskim. Aby udostępniać cyfrowo publikacje z Europy, wystarczyłoby podpisanie porozumienia z Europeaną ${ }^{31}$.

\section{Podsumowanie}

Robert Darnton w swoich publikacjach opisuje problemy, przed jakimi staje naukowe bibliotekarstwo w Stanach Zjednocznoych, jednak wiele z tych sytuacji już jest albo za chwilę będzie polskim udziałem. Warto zacząć wcześniej wyciągać wnioski, aby za jakiś czas nie trzeba było przerywać zakupu publikacji. Między elementami takimi, jak: ceny czasopism, zakup monografii, wydawanie e-booków, blokowanie rozwoju nauki i młodych naukowców, bankructwa wydawnictw naukowych, zachodzą wzajemne zależności. Jeśli zależności te choćby w jednym miejscu zostaną pozbawione harmonii, będą rzucały się cieniem na wszystkie pozostałe. Zasada efektu motyla odbije się na rozwoju humanistyki, która jest dziedziną niezależną, nauką dla nauki, niestymulowaną przez chęć

${ }^{30}$ Tenże, The Library in the New Age...: „Electronic enterprises come and go. Research libraries last for centuries".

${ }^{31}$ Tenże, Google's Loss... 
zarobku czy rozwoju gospodarki, ale przez chęć poznania i opisania świata oraz pragnienie zmieniania go. Gender studies są tu jedynie przykładem, przedstawicielem tendencji w nauce, mód naukowych, które zyskując popularność, pośrednio wpływały na rynek wydawniczy, a także na przyszłość, zarządzanie i funkcjonowanie bibliotek akademickich. Książnice zakupują specjalistyczne czasopisma oraz publikacje poświęcone intensywnie rozwijającym się studiom interdyscyplinarnym, zaniedbując tym samym niszowe monografie. Aby ich autorzy mogli przyczynić się do rozwoju nauki, muszą wydawać je on-line, na zasadzie wolnych licencji. Lekarstwem na harmonijny rozwój nauki oraz funkcjonowanie bibliotek jest otwarta nauka, publikacje wydawane na wolnych licencjach, dostępne dla każdego, wszędzie, bez ograniczeń. Połączenie OA z masową digitalizacją kulturowego dziedzictwa będzie dawało całościowy obraz bogactwa kulturalnego, jego meandrów, kierunków rozwoju i tendencji. Aby dostrzec te walory w polskim środowisku, potrzebna jest zmiana myślenia, zmiana postrzegania nauki. Pracownicy naukowi muszą przestać myśleć, że to, co jest dostępne on-line, za darmo, jest mniej ważne, mniej prestiżowe niż to, co wydrukowane. Stanowi to pole do działania dla bibliotekarzy, którzy powinni uzmysłowić naukowcom przyszłość, jaka maluje się przed nimi. Bez zmian systemowych i prawnych, bez zarządzeń władz uczelnianych najwyższego szczebla oraz bez mody na otwartość w nauce wysiłki bibliotekarzy zostaną jednak tylko i wyłącznie zmarnowaną energią.

\title{
How gender studies affects the future of academic libraries? The vision of the university library by Robert Darnton
}

\begin{abstract}
Not only is this article an attempt of reconstruction Darnton's views concerning books, libraries and researches but also shows its near future. The author is trying to decode a vicious circle which everyone seems to be within - librarians in academic libraries, scientists and publishers. Mentioned trap starts with reviews' high prices - while libraries must pay for delivering permanent magazines, they find themselves not having enough money to spend on monographs. In this situation, when even obliged libraries are not purchasing such releases, editors are not willing to publish them due to minimal expected income. It's becoming clear that such state can be broken down only by changing philosophy of life - meaning moving scientists to "open access" publishing.
\end{abstract}


Scientific releases, published by editors associations, emerge thanks to public resources. However they are inaccessible for regular tax-payers. Franckly speaking the clue is that libraries are forced to buy their own people releases. This is becoming frustrating for most of scientists so that's why they decided to share their work in "open access" manner. If such behavior was promoted and maintained by research institutions it would give an opportunity for development. The most significant achievement here is that science can be made less dependent from economy and industries what obviously brings it closer to its essentiality.

KEYWoRDS: academic libraries, Darnton Robert (1939-), gender studies, Open Access 